\title{
Distribution of secreted aspartyl protease (SAP) virulence genes and antifungal resistance genes at vulvovaginal candidiasis isolates
}

\author{
Ali Aya *, Azab Marwa and Abdelrahman Ali \\ Microbiology and Immunology Department, Faculty of Pharmacy, Suez Canal University, Egypt.
}

Publication history: Received on 14 August 2018; revised on 25 September 2018; accepted on 21 October 2018

Article DOI: https://doi.org/10.30574/gscbps.2018.5.3.0149

\begin{abstract}
Virulence factors and antifungal resistance features of Candida albicans considering a growing health problem worldwide. This study made to show the expression of both virulence and azole resistance genes at 100 clinical isolates of Candida we used a model of infection of human vaginal epithelial cells with $C$. albicans strains isolated from Egyptian women with vulvovaginal candidiasis (VVC). The detection and expression of virulence genes and azole resistance genes were performed using PCR technic. All isolates were susceptible to ketoconazole (KTC), 3 isolates (3\%) only were resist to both nystatin (NY) and amphotericin B (AMB) ,all isolates found resist to griseofulvin (AGF) $10 \mu \mathrm{g}$, eighty five isolates (85\%)were resist to flucytosine (AFY), four isolates (4\%)were resist to miconazole (MCL), seventy one isolates (71\%) were resist to voriconazole (VO), thirty three isolates (33\%) were resist to itraconazole (ITC), forty one isolates and twenty seven isolates (27\%)were resist to $100 \mu \mathrm{g}$ fluconazole (flu). All isolated strains expressed SAP4SAP6 (100\%) and almost all expressed SAP1-SAP3 (91\%) In this study, fluconazole resistance was identified in 27\% of the strains, whereas (27\%) had positive ERG11 gene, (27\%) were positive MDR1 gene and (14\%) were positive CDR1 gene. The results indicate that the strains that infect Egyptian patients suffering from VVC are highly virulent and virtually all are insensitive to fluconazole.
\end{abstract}

Keywords: Candida albicans; SAP gene; Fluconazole; Virulence; Vulvovaginal candidiasis (VVC); Antifungal resistance gene

\section{Introduction}

Candida albicans is a domain fungal species of the human microbiota and asymptomatically colonizes healthy people. Also, it is an opportunistic microorganism which can cause fatal bloodstream infections [1]. C. albicans is the prevalent cause of invasion the fungal infections [2] and represents a serious challenge with increasing the medical and the economic importance due to the high mortality rates and increased costs of care and duration of hospitalization [3], [4].Clinical strains of $C$. albicans have many virulence genes that directly influence the pathogenesis of vulvovaginal candidiasis (VVC), including genes responsible for phenotypic switching [5], HWP1 (hyphal wall protein 1) [6] ALS(agglutinin-like sequence) [7], SAP (secreted aspartyl proteases), PL (phospholipases) [8], and LIP (lipases) [9] The aspartyl proteases, phospholipases, and lipases are involved in the breakdown of cell membranes in host epithelia, which promotes colonization and invasion [10].

The raising of $C$. albicans resistant to antifungal agents, spicially to azoles, is a serious health problem and hampers the treatment of VVC. Many mechanisms responsible for azoles resistance include overexpression of CDR1 and CDR2 from the ABC transporter family and MDR1 which encodes a multidrug efflux pump. Mutations in ERG5 and ERG11, which

\footnotetext{
${ }^{*}$ Corresponding author

E-mail address: Ayamousa1988@gmail.com
}

Copyright (C) 2018 Author(s) retain the copyright of this article. This article is published under the terms of the Creative Commons Attribution Liscense 4.0. 
cause alterations in C22-desaturase and sterol 14 $\alpha$-demethylase, respectively, are also associated with azole resistance [11].

The expression of ALS and SAP gene families in C. albicans of vaginal origin has recently been studied [12-13]. Secreted aspartyl proteinases (Saps), encoded by the SAP gene family with 10 members, (SAP1-SAP10) have a major role in $C$. albicans virulence during fungal infections [14-15].

Development of molecular techniques for targeted gene disruption in diploid eukaryotic organisms recently gives a powerful genetic tool to address virulence studies in C. albicans. Destruction of SAP1-SAP3 genes affected the vaginopathic potential of the strain was previously reported in vitro studies [16]. Using Sap-deficient mutants, different researchers showed that Sap1-Sap 3 have major role in experimental mucosal infections. On the other hand, Sap4-Sap6 appear to be critical for systemic infections [17-18].

The aim of our study was to investigate the Sap distribution among different $C$. albicans isolates using SAP specific primers in polymerase chain reaction (PCR) assay then relationship with resistance gens distribution among our isolates.

\section{Material and methods}

\subsection{Patients analyzed and sampling}

One hundred and fifty-seven (157) vaginal swabs were obtained from women aged from (15 to 45 years old) which clinically diagnosed of genitourinary tract infections attending to AL-Sabaa Banat health care unit and obstetrics and gynecology private clinic. The lower vagina (vaginal introitus) was swabbed. One vaginal swab was collected from each patient with an informed consent.

The vaginal swabs were placed into Sabouraud dextrose broth (SDB) (Difico, USA) transporting media. The transporting media maintained Candida viability for up to 4 days at room temperature or under refrigeration [19].

SDB (Difico, USA) Transporting media was prepared according to manufacturer's instruction: 30 grams were suspended in $1000 \mathrm{ml}$ of cold distilled water heated to dissolve, sterilized by autoclaving then distributed into $15 \mathrm{ml}$ capped plastic tubes and stored in a cool place. Sterile cotton-tipped swabs were used to collect the specimen. Each vaginal swab then was pushed down the medium depth. Swabs were kept cool, in an insulated box containing sufficient ice packs, during the transport period [19].

\subsection{Identification of C. albicans}

C. albicans strains were identified by the API 20C AUX (bioMérieux, France), germ tube test [13], and multiplex PCR (the primers are shown in Table 1) [20]. The DNA of the strains was extracted as described in (BIO FLUX, USA).

Table 1 Primer sequences and PCR conditions for multiplex PCR

\begin{tabular}{|c|c|c|}
\hline Target gene & PCR primer sequences $5 "-3 "$ & PCR conditions \\
\hline ITS1F gene & (5-CCAGCG CTT AAT TGC G-3) [20] & \multirow{7}{*}{$\begin{array}{l}\text { Initial denaturation, } 92^{\circ} \mathrm{C} 2 \mathrm{~min} \text {; } 35 \\
\text { cycles of denaturation }\left(95^{\circ} \mathrm{C}, 1 \mathrm{~min}\right) \text {, } \\
\text { annealing }\left(50^{\circ} \mathrm{C}, 1 \mathrm{~min}\right) \text {, and } \\
\text { extension }\left(72{ }^{\circ} \mathrm{C}, 1 \mathrm{~min}\right) \text { and } \\
\text { final extension, } 72{ }^{\circ} \mathrm{C}, 10 \mathrm{~min} \\
{[20]}\end{array}$} \\
\hline ITS1K gene & (5-ATC GTC TGA ACA AGGCCT GC-3) [20] & \\
\hline ITS2D gene & (5-GAG AAC CAA GAG ATC CGT TGTTG-3) [20] & \\
\hline ITS1 gene & (5-TCC GTA GGT GAA CCTGCG G-3) [20] & \\
\hline ITS2 gene & (5-GCT GCG TTC TTC ATC GAT CG-3[20] & \\
\hline CA3 gene & (5-GGT TTG GAAAGA CGG TAG-3) [20] & \\
\hline CA4 gene & (5-AGT TTG AAG ATA TAC GTGGTA G-3) [20] & \\
\hline
\end{tabular}

PCR reaction was performed in a $50 \mu \mathrm{l}$ volume containing $20 \mu \mathrm{l}$ vaginal swab broth solution, 5X PCR buffer (Thermo, USA), $2.5 \mathrm{mM} \mathrm{MgCl} 2$ (Thermo, USA), $630 \mu \mathrm{M}$ PCR nucleotide Mix - $10 \mathrm{mM}$ each (Thermo, USA), $2 \mu$ from each 7 primers, $1 \mu \mathrm{l}$ Go Tag DNA Polymerase (Fermentase, USA). The volume for each PCR reaction was completed to $50 \mu$ l with nuclease free water (Thermo, USA) [20] 
PCR products were analyzed by electrophoresis through a 2\% agarose gel (Bioshop, Canada) containing ethidium bromide (Sigma, USA), and UV visualization were performed according to the protocols provided (G: box, SYNGENE, Cambridge, England). The length of the bands was measured by UV Light software according to (table 2) and reference Candida albicans strain (ATCC 90028) used to compare the result with it [20].

Table 2 List of the primers and the generated PCR products

\begin{tabular}{lcccccccc}
\hline \multicolumn{1}{c}{ Organism } & ITS1 & ITS1F & ITS1K & ITS2 & ITS2D & CA3 & CA4 & PCR product (bp) \\
\hline C. glabrata & + & - & - & + & + & - & - & $482-483 / 462-463$ \\
C. guilliermondii & + & - & - & + & + & - & - & $248 / 228$ \\
C. famata & - & + & - & + & + & - & - & $234 / 214$ \\
C. kefyr & - & - & + & + & + & - & - & $249 / 229$ \\
C. parapsilosis & + & - & - & + & + & - & - & $229 / 209$ \\
C. tropicalis & + & - & - & + & + & - & - & $218 / 199$ \\
C. albicans & + & - & - & + & + & + & + & $218-219 / 198-199 / 110$ \\
C. krusei & + & - & - & + & + & - & - & $182 / 166$ \\
C. lusitaniae & + & - & - & + & + & - & - & $148 / 128$ \\
C. dubliniensis & + & - & - & - & + & - & - & 198 \\
\hline
\end{tabular}

\subsection{Antifungal susceptibility}

Pure SDA isolates were tested for susceptibility to 9 antifungal using disk diffusion method according to the Clinical and Laboratory Standards Institute (CLSI formely NCCLS) guidelines [21]. The antifungal disks used were Nystatin (NY) 100 $\mu \mathrm{g}$, Griseofulvin (AGF) $10 \mu \mathrm{g}$ Amphotericin B (AMB) $20 \mu \mathrm{g}$, Flucytosine (AFY) $1 \mu \mathrm{g}$, Itraconazole (ITC) have 2 concentrations $8 \mu \mathrm{g}$ and $15 \mu \mathrm{g}$, Fluconazole (FLU) have 2 concentrations $25 \mu \mathrm{g}$ and $100 \mu \mathrm{g}$, ketoconazole (KTC) have 2 concentrations $10 \mu \mathrm{g}$ and $15 \mu \mathrm{g}$, Miconazole (MCL) $10 \mu \mathrm{g}$, and Voriconazole (VO) $1 \mu \mathrm{g}$. All antifungal disks were purchased from LIOFILCHEM, Italy.

\subsection{Detection of resistance genes by PCR}

Candida nucleic acid detection was based on four genes, these genes responsible for resistance character shown in Candida spp to flouconazole. These genes were: CDR1, CDR2, MDR1 and ERG11. PCR reaction was performed in a $50 \mu \mathrm{l}$ volume containing $2 \mu \mathrm{l}$ DNA template, 5X PCR buffer (Thermo, USA), $2.5 \mathrm{mM} \mathrm{MgCl}_{2}$ (Thermo, USA), $625 \mu \mathrm{M}$ PCR nucleotide Mix - $10 \mathrm{mM}$ each (Thermo, USA), $2 \mu$ upstream primer (Bio Basic, Canada), $2 \mu \mathrm{l}$ downstream primer (Bio Basic,Canada), $1 \mu$ Go Taq DNA Polymerase (Fermentas, USA). The volume for each PCR reaction was completed to $25 \mu \mathrm{l}$ with nuclease free water (Thermo, USA). DNA amplification was carried out in a Gradient Thermacycler (MyCycler, BIORAD). Table 3 gives the primer sequences, PCR amplicon size and PCR reaction conditions for each target gene. The sizes of the PCR products were determined by comparing them with the migration of 100-bp DNA ladder (Axygene, USA)[2223].

Table 3 Primer sequences used in PCR

\begin{tabular}{|c|c|c|c|c|}
\hline Target gene & $5 "-3 "$ & PCR Primer sequences & PCR conditions & $\begin{array}{l}\text { Amplicon } \\
\text { Size }\end{array}$ \\
\hline ERG11 gene & $\begin{array}{l}\text { 5"- } \\
\text { GTCAAATCATTCAAATCACCACCT } \\
-3 "\end{array}$ & $\begin{array}{l}\text { 5"- } \\
\text { GGTGGTCAACATACTTCTGCTTC- } \\
\text { 3" }\end{array}$ & $\begin{array}{l}\text { One cycle at } 95^{\circ} \mathrm{C} \text { for } \\
5 \text { min, followed by } \\
30 \text { cycles of } 95^{\circ} \mathrm{C} \text { for }\end{array}$ & $204 \mathrm{bp}$ \\
\hline MDR1 gene & $\begin{array}{l}\text { 5"- } \\
\text { CCAAAGCAGTGGGGATTTGTAG- } \\
\text { 3" }\end{array}$ & $\begin{array}{l}\text { 5"- } \\
\text { GTGTTGGCCCATTGGTTTTCAGTC- } \\
\text { 3" }\end{array}$ & $\begin{array}{l}30 \mathrm{~s}, 60{ }^{\circ} \mathrm{C} \text { for } 30 \mathrm{~s} \text {, } \\
\text { and } 72{ }^{\circ} \mathrm{C} \text { for } 30 \mathrm{~s} \text {, } \\
\text { followed by one }\end{array}$ & $201 \mathrm{bp}$ \\
\hline CDR1 gene & $\begin{array}{l}5 "- \\
\text { CGACGGATCACCTTTCATACGA- } \\
3 "\end{array}$ & 5"-TGCCAAACAATCCAАCAA- 3" & $\begin{array}{l}\text { cycle at } 72{ }^{\circ} \mathrm{C} \text { for } 7 \\
\min [22] .\end{array}$ & $286 \mathrm{bp}$ \\
\hline CDR2 gene & 5"-GTCGGACATGTGGCTCAAA-3" & 5"-AAGGTTTTGATGCTACTGC-3" & & $364 \mathrm{bp}$ \\
\hline
\end{tabular}




\subsection{Detection of SAP virulence genes by PCR}

Table 4 SAP specific primers

\begin{tabular}{|c|c|}
\hline Gene(s) & Primers \\
\hline SAP1-SAP3 (F) & $5^{\prime}$-GCT CTT GCT ATT GCT TTA TTA G-3'[24] \\
\hline SAP1-SAP3 (R) & 5'-CAT CAG GAA CCC ATA AAT CAG-3'[24] \\
\hline SAP4-SAP6 (F) & $5^{\prime}$-GCT CTT GCT ATT GCT TTA TTA G-3’[24] \\
\hline SAP4 (R) & 5'-TAG GAA CCG TTA TTC TTA CA-3’ [24] \\
\hline SAP5 (R) & 5'-ACC TAA AAT ACC CTT ACG AG-3'[24] \\
\hline SAP6(R) & 5'-GGT AGC TTC GTT GGT TTG GA-3'[24] \\
\hline
\end{tabular}

Selection of SAP specific primers. SAP1-SAP3 genes were amplified by using one (the same) primer pair; one primer pair for SAP4, one primer pair for SAP5 and one primer pair for SAP6 were used in the assay (Table 4). The same forward primer was used for amplification of SAP4-SAP6 genes, while reverse primers were different [17], [25-26].

Amplification procedure. The standard PCR mixture contained $0.5 \mathrm{U}$ of Taq DNA polymerase, $200 \mathrm{~mol} / \mathrm{L}$ of deoxynucleoside triphosphates, $10 \mathrm{pmol}$ of each primer, $25 \mathrm{mmol} / \mathrm{L}$ of $\mathrm{MgCl}_{2}, 10 \times$ of buffer in $25 \mathrm{~L}$ of PCR mixture. PCR was performed in a thermal cycler (Techne, UK) was done as follows: 5 min at $95^{\circ} \mathrm{C}, 30$ cycles of $30 \mathrm{~s}$ at $95{ }^{\circ} \mathrm{C}, 45 \mathrm{~s}$ at $58{ }^{\circ} \mathrm{C}, 1 \mathrm{~min}$ at $72{ }^{\circ} \mathrm{C}$, then terminal step $\left(5 \mathrm{~min}, 72^{\circ} \mathrm{C}\right)$, and the mixture was held at $4{ }^{\circ} \mathrm{C}$. The PCR products were separated by $2 \%$ agarose gel electrophoresis, stained with ethidium bromide, and visualized with UV light [17], [25-26]. SAP1-SAP3 has band at $253 \mathrm{bp}$, SAP4 give band at $106 \mathrm{bp}$, while SAP5 band observed at 267 bp and SAP6 give positive product at $314 \mathrm{bp}[24]$.

\section{Results}

\subsection{Identification of $C$. albicans and antifungal resistance phenotypes}

The present study was conducted with a total of 157 women clinically diagnosed of genitourinary tract infections and by using the conventional culture technique only 100 isolates were identified as Candida with a prevalence rate (64\%). These isolates showed $27 \%$ resistance to fluconazole. Ninety eight (98) isolates (98\%) identified as Candida albicans which give the same bands of Candida albicans reference strain (ATCC 90028) at (218-219 bp), (198_199 bp), (110 bp) while 2 isolates (2\%) found Candida glabrata show bands at (482-483 bp), (462-463bp).

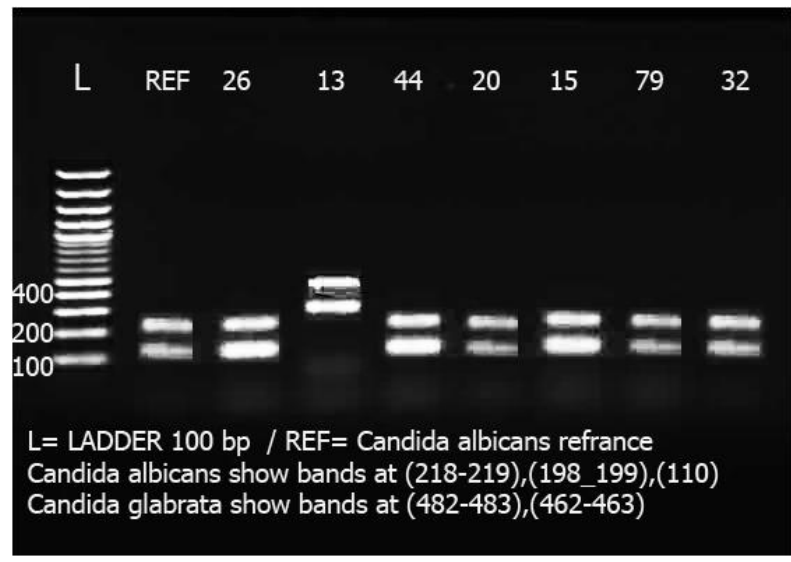

Figure 1 Identification by multiplex PCR

\subsection{Antifungal susceptibility testing}

All the Candida sp isolates were susceptible to $10 \mu \mathrm{g}$ and $15 \mu \mathrm{g}$ ketoconazole (KTC). Resistance to nystatin (NY) $100 \mu \mathrm{g}$ was detected in 3 isolates (3\%). All isolates found resist to griseofulvin (AGF) $10 \mu \mathrm{g}$. Three isolates (3\%) were resist to amphotericin B (AMB) $20 \mu \mathrm{g}$, eighty five isolates (85\%) were resist to flucytosine (AFY) $1 \mu \mathrm{g}$, four isolates (4\%) were 
resist to miconazole (MCL) $10 \mu \mathrm{g}$, seventy one isolates (71\%) were resist to voriconazole (VO) $1 \mu \mathrm{g}$, thirty seven isolates (37\%) were resist to $8 \mu \mathrm{g}$ itraconazole (iTC), thirty three isolates (33\%) were resist to $50 \mu \mathrm{g}$ itraconazole (iTC), forty one isolates (41\%) were resist to $25 \mu \mathrm{g}$ fluconazole (flu) and twenty seven isolates (27\%)were resist to $100 \mu \mathrm{g}$ fluconazole (flu), (Table 5).

Table 5 Percentage of resistance for antifungal agents

\begin{tabular}{lc}
\hline Antifungal & Resistance (\%) \\
\hline Ketoconazole (KTC) $10 \mu \mathrm{g}$ & $0 \%$ \\
Ketoconazole (KTC) $15 \mu \mathrm{g}$ & $0 \%$ \\
Nystatin (NY) 100 $\mu \mathrm{g}$ & $3 \%$ \\
Griseofulvin (AGF) $10 \mu \mathrm{g}$ & $100 \%$ \\
Amphotericin B (AMB) $20 \mu \mathrm{g}$ & $3 \%$ \\
Flucytosine (AFY) $1 \mu \mathrm{g}$ & $85 \%$ \\
Miconazole (MCL) $10 \mu \mathrm{g}$ & $4 \%$ \\
Voriconazole (VO) $1 \mu \mathrm{g}$ & $71 \%$ \\
Itraconazole (iTC) $8 \mu \mathrm{g}$ & $37 \%$ \\
Itraconazole (iTC) $50 \mu \mathrm{g}$ & $33 \%$ \\
Fluconazole (flu) $25 \mu \mathrm{g}$ & $41 \%$ \\
Fluconazole (flu) $100 \mu \mathrm{g}$ & $27 \%$ \\
\hline
\end{tabular}

\subsection{Detection of azole resistance genes}

Twenty-seven specimens (27\%) were positive ERG11 gene showed characteristic band at 204 bp (Figure 2). Twentyseven specimens (27\%) were positive MDR1 gene showed characteristic band at 201 bp in size (Figure 2). Only fourteen specimens (14\%) were positive CDR1 gene showed band at $286 \mathrm{bp}$ (Figure 2). No specimens showed characteristic bands at $364 \mathrm{bp}$ for CDR2.

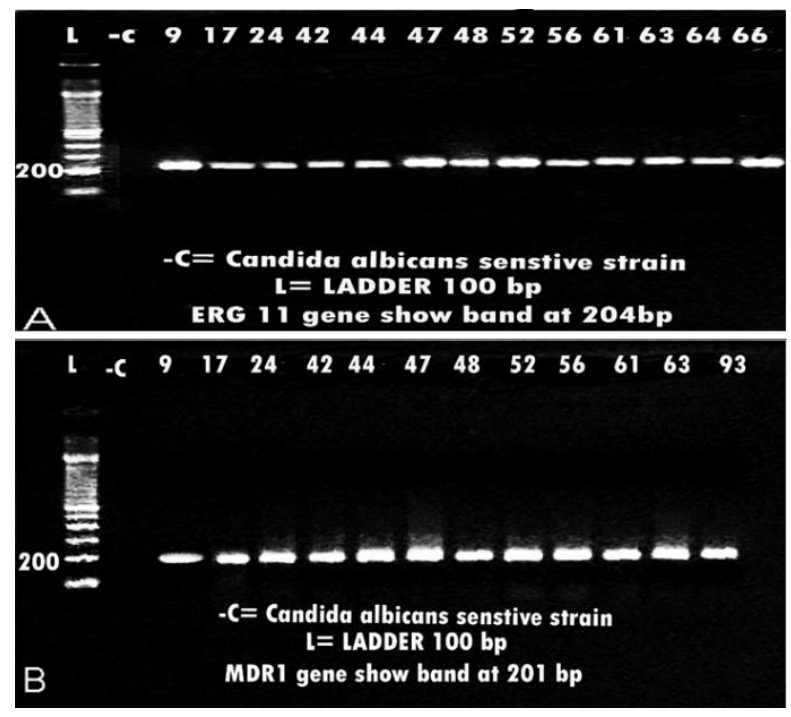

Figure 2 ERG11 (A) and MDR1 (B) genes in resistant isolates 


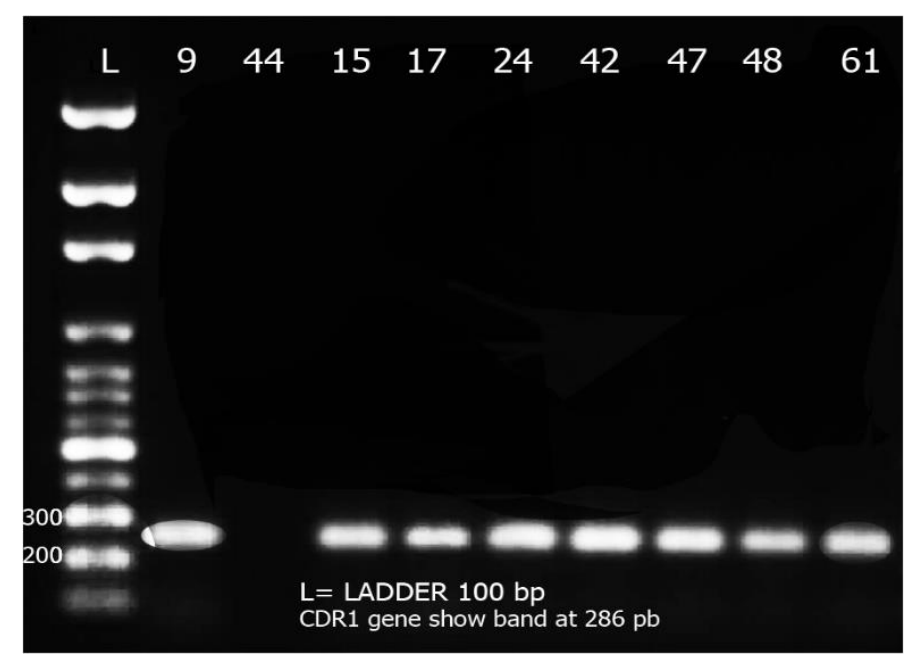

Figure 3 CDR1 gene in resistant isolates

\subsection{Detection of SAP virulence genes}

One hundred specimens (100\%) were positive SAP4-SAP6 genes, SAP4 showed characteristic band at 106 bp, while SAP 5 give band at $267 \mathrm{bp}$ and SAP6 show band at $314 \mathrm{bp}$ (Figure 5). Ninety-one specimens (91\%) were positive SAP1SAP3 gene showed characteristic band at 253 bp (Figure 4).

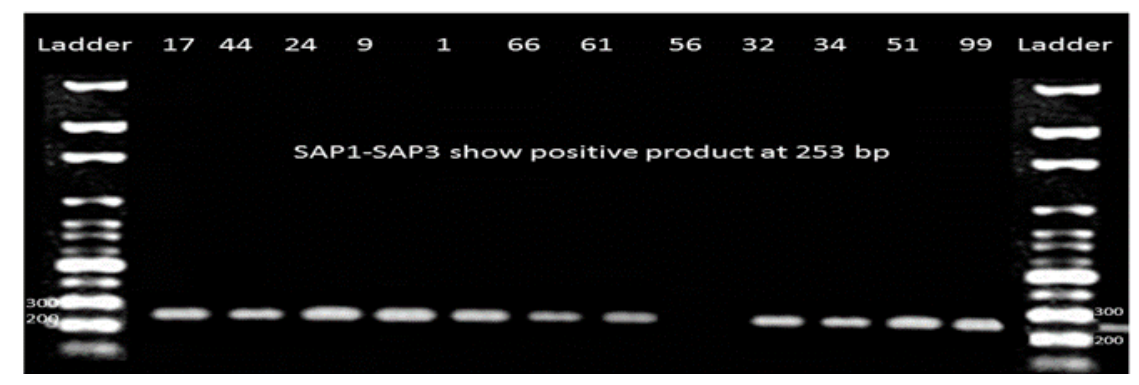

Figure 4 SAP1-SAP3 gene in clinical isolates

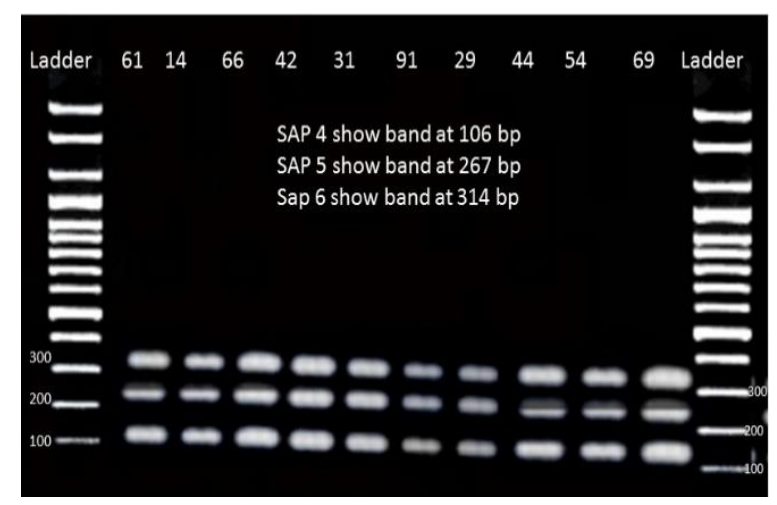

Figure 5 SAP4-SAP6 gene in clinical isolates

\section{Discussion}

In this study, we isolated and identified both resistance and SAP virulence gene of $C$. albicans strains in vaginal samples. VVC is a condition that affects a quarter of young women [27]. The chronicity of VVC or recurrent episodes by $C$. albicans is due to prolonged use of antifungal agents, which select for resistant strains, and due to the many virulence genotypes that enhance the adhesion to epithelial cells, production of hydrolytic enzymes, colonization, and invasion [10]. The observation in this study that C. albicans had the high incidence rate (63.69\%) among the yeast isolates studied agrees with the reports of other workers [28], [29]. 
This study used highly sensitive method for the detection of $C$. albicans SAP-expression directly in yeast DNA samples. To investigate each Sap isoenzyme, we individually used SAP specific primers in PCR screening. We used 4 different specific primer pairs for SAP1-SAP3, SAP4, SAP5 and SAP6[24]. Likewise, all isolated strains expressed SAP4SAP6 (100\%) and almost all expressed SAP1-SAP3 (91\%). These results are similar to those previously described for SAP expression in VVC in humans [30]. The expression of SAP4-SAP6 has a relevant role in pathogenesis by promoting hyphae formation [31] and by the inhibition of phagocytosis [32].

The use of azoles for the treatment of VVC for prolonged time has resulted in the promote of strains resistant to these agents [28]. In this study, fluconazole resistance was identified in 27\% of the strains (Table 5), whereas (27\%) had positive ERG11 gene, (27\%) were positive MDR1 gene and (14\%) were positive CDR1 gene. The high frequencies of strains resistant to fluconazole can be explained by many such as incomplete therapy, over growth of resistant strains, and induction of drug resistance in the particular species, colonization and subsequent infection with a resistant organism [33], [34]. The reason in our study is due to self-treatment and drug abuse of the patient. Therefore, in vitro testing of the susceptibility of yeasts to antifungal agents will likely play an ever-increasing role in the appropriate selection of antifungal agents for the treatment of fungal infections. Nonetheless, the high susceptibility rate of Candida species to ketoconazole drugs so can use as azole antifungal agent for treatment genitourinary tract infections among women in Egypt.

\section{Conclusion}

The results show that the strains that infect Egyptian women suffering from VVC are highly virulent and virtually all are insensitive to fluconazole. These results help in identification of resistance and virulence patterns of strains causing VVC in Egypt. Further researches on different agents are required to solve this issue.

\section{Compliance with ethical standards}

\section{Acknowledgments}

The authors will like to thank the Faculty of Pharmaceutical Sciences Suez Canal University, Ismailia, Egypt.

\section{Disclosure of conflict of interest}

The authors declare that there is no conflict of interest.

\section{References}

[1] Lohse MB, Gulati M, Johnson AD and Nobile CJ. (2017). Development and regulation of single-. Nature Publishing Group, 16(1), 19-31.

[2] Horn DL, Neofytos D, Anaissie EJ and Fishman JA. (2009), Epidemiology and outcomes of candidemia in 2019 patients: data from the prospective antifungal therapy alliance registry. Clinical infectious diseases : an official publication of the Infectious Diseases Society of America, 48(12), 1695-1703.

[3] Almirante B, Rodríguez D, Park BJ and Cuenca-Estrella M. (2005). Epidemiology and predictors of mortality in cases of Candida bloodstream infection: results from population-based surveillance, Barcelona, Spain, from 2002 to 2003. Journal of Clinical Microbiology, 43(4), 1829-1835.

[4] Lai CC, Wang CY, Liu WL and Huang YT. (2012). Time to positivity of blood cultures of different Candida species causing fungaemia. Journal of medical microbiology, 61(5), 701-704.

[5] Hellstein J, Vawter-Hugart H, Fotos P and Schmid J. (1993). Genetic similarity and phenotypic diversity of commensal and pathogenic strains of Candida albicans isolated from the oral cavity. Journal of clinical microbiology, 31(12), 3190-3199.

[6] Sobel JD, Faro S, Force RW and Foxman B. (1998). Vulvovaginal candidiasis: epidemiologic, diagnostic, and therapeutic considerations. American journal of obstetrics and gynecology, 178(2), 203-211.

[7] Zhao X, Oh SH, Cheng G and Green CB. (2004). ALS3 and ALS8 represent a single locus that encodes a Candida albicans adhesin; functional comparisons between Als3p and Als1p. Microbiology, 150(7), 2415-2428.

[8] Hube B. (1998). Possible role of secreted proteinases in Candida albicans infections. Revista iberoamericana de micología, 15, 65-68. 
[9] Hube B, Stehr F, Bossenz M and Mazur A. (2000). Secreted lipases of Candida albicans: cloning, characterisation and expression analysis of a new gene family with at least ten members. Archives of microbiology, 174(5), 362374.

[10] Schaller M, Borelli C, Korting HC and Hube B. (2005). Hydrolytic enzymes as virulence factors of Candida albicans. Mycoses, 48(6), 365-377.

[11] Manastır L, Ergon MC and Yücesoy M. (2011). Investigation of mutations in Erg11 gene of fluconazole resistant Candida albicans isolates from Turkish hospitals. Mycoses, 54(2), 99-104.

[12] Monroy-Pérez E, Paniagua-Contreras, G, Vaca-Paniagua F and Negrete-Abascal E. (2013). SAP expression in Candida albicans strains isolated from Mexican patients with vaginal candidosis. International Journal of Clinical Medicine, 4(01), 25.

[13] Monroy-Pérez E, Sáinz-Espuñes T, Paniagua-Contreras G and Negrete-Abascal E. (2012). Frequency and expression of ALS and HWP1 genotypes in Candida albicans strains isolated from Mexican patients suffering from vaginal candidosis. Mycoses, 55(3), e151-e157.

[14] De Bernardis F, Sullivan PA and Cassone A. (2001). Aspartyl proteinases of Candida albicans and their role in pathogenicity. Sabouraudia, 39(4), 303-313.

[15] Hamal P, Dostál J, Raclavský V and Krylová M. (2004) Secreted aspartate proteinases, a virulence factor of Candida spp.: occurrence among clinical isolates. Folia microbiologica, 49(4), 491-496.

[16] De Bernardis F, Arancia S, Morelli L and Hube B. (1999). Evidence that members of the secretory aspartyl proteinase gene family, in particular SAP2, are virulence factors for Candida vaginitis. The Journal of infectious diseases, 179(1), 201-208.

[17] Felk A, Kretschmar M, Albrecht A and Schaller M. (2002). Candida albicans hyphal formation and the expression of the Efg1-regulated proteinases Sap4 to Sap6 are required for the invasion of parenchymal organs. Infection and immunity, 70(7), 3689-3700.

[18] Schaller M, Schackert C, Korting HC and Januschke E. (2000). Invasion of Candida albicans correlates with expression of secreted aspartic proteinases during experimental infection of human epidermis. Journal of investigative dermatology, 114(4), 712-717.

[19] Bhavan PS, Rajkumar R, Radhakrishnan S and Seenivasan C. (2010). Culture and Identification of Candida albicans from Vaginal Ulcer and Separation of Enolase on SDS-PAGE. International Journal of Biology, 2(1), 84.

[20] Liguori G, Lucariello A, Colella G and De Luca A. (2007). Rapid identification of Candida species in oral rinse solutions by PCR. Journal of clinical pathology, 60(9), 1035-1039.

[21] Wayne PA. (2004). Method for antifungal disk diffusion susceptibility testing of yeasts. CLSI m44-a.

[22] Frade JP, Warnock DW and Arthington-Skaggs BA. (2004). Rapid quantification of drug resistance gene expression in Candida albicans by reverse transcriptase LightCycler PCR and fluorescent probe hybridization. Journal of clinical microbiology, 42(5), 2085-2093.

[23] Ricardo E, Costa-de-Oliveira S, Silva Dias A and Guerra J. (2009). Ibuprofen reverts antifungal resistance on Candida albicans showing overexpression of CDR genes. FEMS yeast research, 9(4), 618-625.

[24] Dostál J, Hamal P, Pavlíčková L and Souček, M. (2003). Simple method for screening Candida species isolates for the presence of secreted proteinases: a tool for the prediction of successful inhibitory treatment. Journal of clinical microbiology, 41(2), 712-716.

[25] Sanglard D, Hube B, Monod M and Odds FC. (1997). A triple deletion of the secreted aspartyl proteinase genes SAP4, SAP5, and SAP6 of Candida albicans causes attenuated virulence. Infection and immunity, 65(9), 35393546.

[26] Hube B, Sanglard D, Odds FC and Hess D. (1997). Disruption of each of the secreted aspartyl proteinase genes SAP1, SAP2, and SAP3 of Candida albicans attenuates virulence. Infection and immunity, 65(9), 3529-3538.

[27] Sobel JD, Muller G and Buckley HR. (1984). Critical role of germ tube formation in the pathogenesis of candidal vaginitis. Infection and immunity, 44(3), 576-580.

[28] Richter SS, Galask RP, Messer SA and Hollis RJ. (2005). Antifungal susceptibilities of Candida species causing vulvovaginitis and epidemiology of recurrent cases. Journal of clinical microbiology, 43(5), 2155-2162. 
[29] Tatfeng M, Agba I, Nwobu $O$ and Agbonlahor E. (2004). Candida albicans in urinary tract or in seminal sac. Online Journal of Health and Allied Sciences, 2(4).

[30] Lian CH and Liu WD. (2007). Differential expression of Candida albicans secreted aspartyl proteinase in human vulvovaginal candidiasis. Mycoses, 50(5), 383-390.

[31] Newport G and Agabian N. (1997). KEX2 influences Candida albicans proteinase secretion and hyphal formation. Journal of Biological Chemistry, 272(46), 28954-28961.

[32] Borg-von Zepelin M, Beggah S, Boggian K and Sanglard D. (1998). The expression of the secreted aspartyl proteinases Sap4 to Sap6 from Candida albicans in murine macrophages. Molecular microbiology, 28(3), 543554.

[33] Rex JH, Rinaldi MG and Pfaller MA. (1995). Resistance of Candida species to fluconazole. Antimicrobial Agents and Chemotherapy, 39(1), p.1.

[34] Powderly WG. (1994). Resistant candidiasis. AIDS research and human retroviruses, 10(8), 925-929.

\section{How to cite this article}

Ali A, Azab M and Abdelrahman A. (2018). Distribution of secreted aspartyl protease (SAP) virulence genes and antifungal resistance genes at vulvovaginal candidiasis isolates. GSC Biological and Pharmaceutical Sciences, 5(3), 8694. 